\title{
Steinmann Pins and Polymethylmethacrylate Repair of Fourth Lumbar Vertebral Fracture and Dorsocranial Luxation in Puppy
}

\author{
Fernando Bezerra da Silva Sobrinho', Ivan Felismino Charas dos Santos², Cláudia Valéria Seullner Brandão², \\ Sheila Canevese Rahal'2, César Passareli Cândido Lobo³, Vânia Maria Vasconcelos Machado², \\ Gabriel Godoi Moraes' \& Tainá Aparecida Pereira da Silva ${ }^{4}$
}

\begin{abstract}
Background: Acute spinal traumas can lead to irreversible damage associated with vascular and inflammatory changes in neural tissue. Since spine and spinal cord traumas have an unfavorable prognosis in small animals, and reports of the use of Steinmann pins and polymethylmethacrylate repair of lumbar vertebra fracture-luxation in puppies are rare in the literature, the present paper aimed to report the surgical treatment of transversal fracture through the body of the fourth lumbar vertebra, with dorsocranial displacement of the caudal fragment by using Steinmann pins and polymethylmethacrylate in a 7-month-old Labrador Retriever male dog.

Case: A 7-month-old intact male Labrador Retriever dog, weighing $24.0 \mathrm{~kg}$ was attended at School Veterinary Hospital with a history of hit by car and paraplegia of the hind limbs. On neurological examination was observed no proprioception and no deep pain sensitivity on the both pelvic limbs. The lumbar spinal palpation showed intense pain, and the motor function and patellar reflexes were reduced. The values of haematological and biochemical analysis remained within the reference values for the species. Radiographs revealed a transversal fracture through the body of the fourth lumbar vertebra, with dorsocranial displacement of the caudal fragment, and was decided to perform a surgical treatment by open reduction and internal fixation of the fracture. The dog was positioned in ventral recumbency for surgery, and a dorsal midline incision was made from the second lumbar vertebra to the sixth lumbar vertebra. Two crossed $1.5 \mathrm{~mm}$ Kirschner wires were placed through the caudal articular facets of the fourth lumbar vertebra to provide initial stability. Two $2.0 \mathrm{~mm}$ Steinmann pins were placed at $60^{\circ}$ angle of the bodies of the second and fifth lumbar vertebrae, and third and fourth lumbar vertebrae. This procedure was repeated on the other side of the vertebral bodies. Sixty grams of polymethylmethacrylate bone cement was applied and the fixation was checked for stability. Muscular, subcutaneous tissue and skin was closed routinely. The dog was paraplegic without any pain and used a wheelchair to assist in locomotion, although it still had urinary and faecal incontinence; no tail control; and the implants were not removed.

Discussion: Lumbar vertebral injuries, as in the present case frequently, occur secondary to severe trauma (e.g. hit by car) and seem to have a characteristic fracture pattern. The patient became paraplegic due to spinal cord injury and failure of sensitivity and elimination of urine and feces which can be associated with progressive destruction of neuronal tissue due to secondary vascular and inflammatory events. The radiographic exam was used to confirm the spinal injury and determine whether by conservative or surgical treatment. The treatment choice is related to the number of fractured compartments, and the presence or not of compression. Fractures in two or more compartments are indicative of surgical treatment, similar as the present case. Use of Steinmann pins was to make a rigid fixing system compared with block plates used for the same function. Use of polymethylmethacrylate may also become a complication due to the infection, for this reason was prescribed an antibiotic for 15 days. This procedure proved to be effective since the dog showed no signs of infection. According to the characteristics of the present case report, the use of Steinmann pins and polymethylmethacrylate for repair of transversal fracture through the body of the fourth lumbar vertebra, with dorsocranial displacement of the caudal fragment provided an effective and practical means of stabilisation, promoting decompression, and thus, improving the patient's quality of life.
\end{abstract}

Keywords: stabilisation, orthopedic implant, small animals, spinal cord, vertebra. 


\section{INTRODUCTION}

Traumatic or non-traumatic injuries of the spine can cause fractures and luxation due to the extrinsic forces, which are unpredicted in orientation and magnitude, and can be superior to the protection capacity of the structural components of the spine, and inducing compression, laceration, concussion of the spinal cord [11].

Fractures and luxation of the lumbar vertebra is a challenge for surgical stabilisation because of the potential for iatrogenic nerve damage [11]. Steinmann pins and polymethylmethacrylate provides good stabilisation of the spine, and can be used in any region of the spine without limitations as age and body mass [6]. The advantage of this surgical technique is related to not requiring special equipment and surgical instruments [6,11].

Since spine and spinal cord traumas have an unfavorable prognosis and are quite common in small animals, and reports of the use of Steinmann pins and polymethylmethacrylate repair of fourth lumbar vertebra fracture and dorsocranial luxation in young dog is rare in the literature, the present paper aims to report the surgical treatment of transversal fracture through the body of the fourth lumbar vertebra, with dorsocranial displacement of the caudal fragment by using Steinmann pins and polymethylmethacrylate in a 7-month-old male Labrador Retriever dog attended at School Veterinary Hospital, School of Veterinary Medicine and Animal Science (FMVZ), São Paulo State University (UNESP), Botucatu, São Paulo, Brazil.

\section{CASE}

A 7-month-old intact male Labrador Retriever dog, weighing $24.0 \mathrm{~kg}$ was attended at School Veterinary Hospital (FMVZ, UNESP) Botucatu, São Paulo,
Brazil with a history of hit by car and paraplegia of the hind limbs. The time between the trauma and attendance was $1 \mathrm{~h}$. The patient was conscious and tachypneic, with no other physiological changes. On neurological examination was observed no proprioception and no deep pain sensitivity on the both pelvic limbs. The lumbar spinal palpation showed intense pain and the motor function and patellar reflexes were reduced. The immediate treatment included methadone ${ }^{1}$ [Myte$\mathrm{dom}^{\circledR} 5 \mathrm{mg} / \mathrm{kg}$, intravenously (IV)]. Blood samples for haematological and biochemical analysis (alanine aminotransferase, total serum protein, albumin, urea, creatinine, sodium and potassium) were obtained from the jugular vein. The values of haematological and biochemical analysis remained within the reference values for the species.

The radiographic exam was performed by using a portable digital radiographic device (MinXray's HF100+ Ultra Light $\left.{ }^{\circledR}\right)^{2}$ for use on ambulatory service. Radiographs revealed a transversal fracture through the body of the fourth lumbar vertebra, with dorsocranial displacement of the caudal fragment (Figure 1). Following the clinical signs and radiographic diagnosis, a surgical treatment by open reduction and internal fixation of the fracture was chosen.

The patient was hospitalized $24 \mathrm{~h}$ before the surgery and medicated with methadone ${ }^{1}\left[\right.$ Mytedom $^{\circledR}$ $0.7 \mathrm{mg} / \mathrm{kg}$, intramusculary (IM)]. The pre-anesthetic medication included methadone ${ }^{1}$ [Mytedom $^{\circledR}$ $0.2 \mathrm{mg} / \mathrm{kg}$ (IV)], and the anesthetic induction was performed with midazolam ${ }^{3}$ [Dormonid ${ }^{\circledR} 0.2 \mathrm{mg} / \mathrm{kg}$ (IV)] and propofol ${ }^{4}$ [Dipivan ${ }^{\circledR} 7 \mathrm{mg} / \mathrm{kg}$ (IV)]. The anesthetic maintenance was performed with isoflurane ${ }^{5}$ [Vetflurano $\left.{ }^{\circledR}\right]$ and oxygen $(100 \%)$ in a closed anesthetic circuit. Epidural infiltrative analgesia using bupivacaine without vasoconstrictor ${ }^{1}\left[\right.$ Neocaína $\left.^{\circledR} 1.1 \mathrm{mg} / \mathrm{kg}\right]$

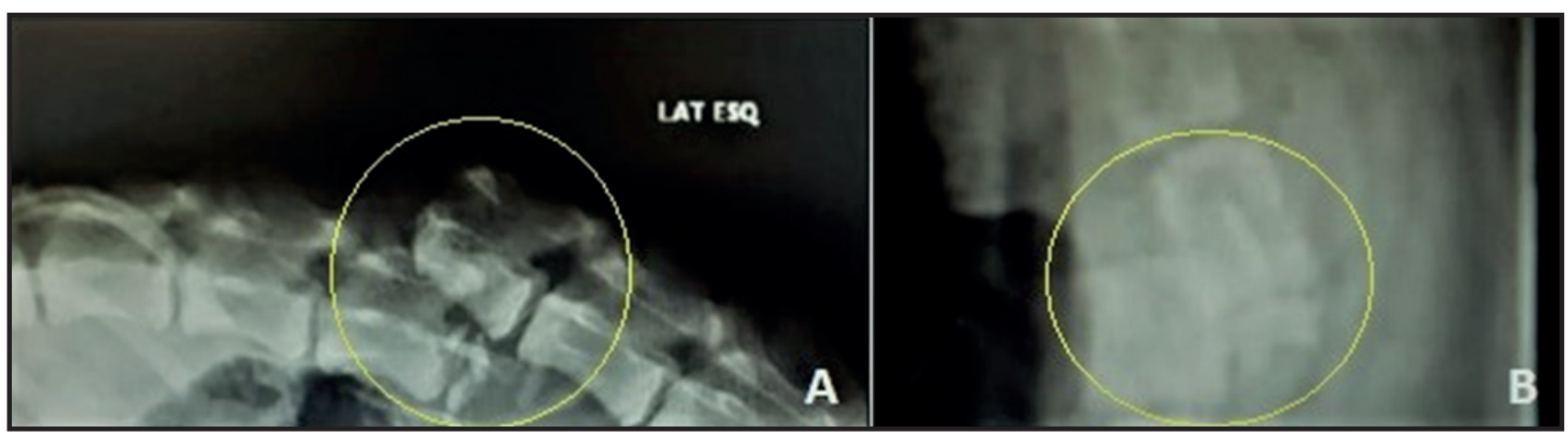

Figure 1. Transversal fracture through the body of the fourth lumbar vertebra, with dorsocranial displacement of the caudal fragment (yellow circle). A- Latero-lateral projection; B- Dorsoventral projection (40 kVp, $40 \mathrm{mAs})$. 


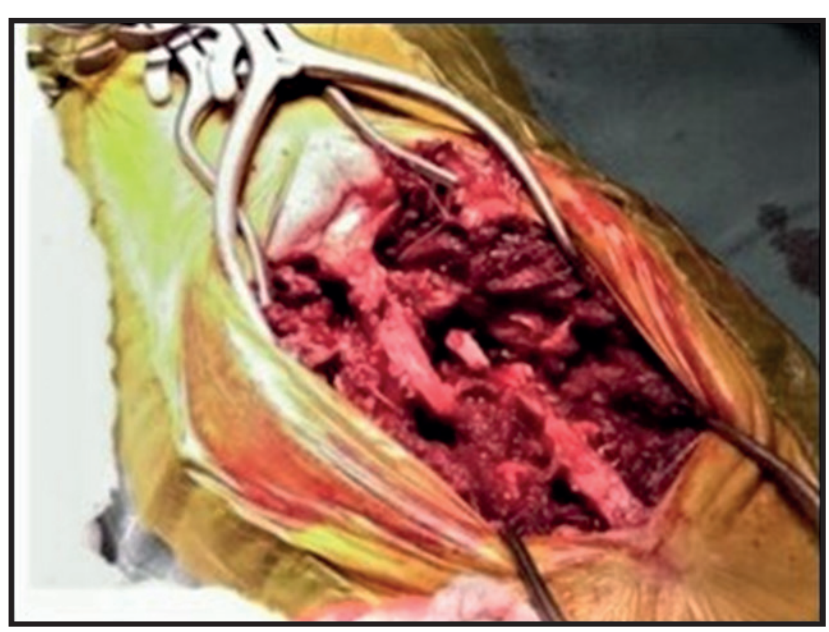

Figure 2. Lumbar fascia dissected and expose the second, third, fourth, fifth and, sixth lumbar spinous processes, and all muscular attachments elevated from both sides of the pedicles and retracted laterally to the level of the articular processes.

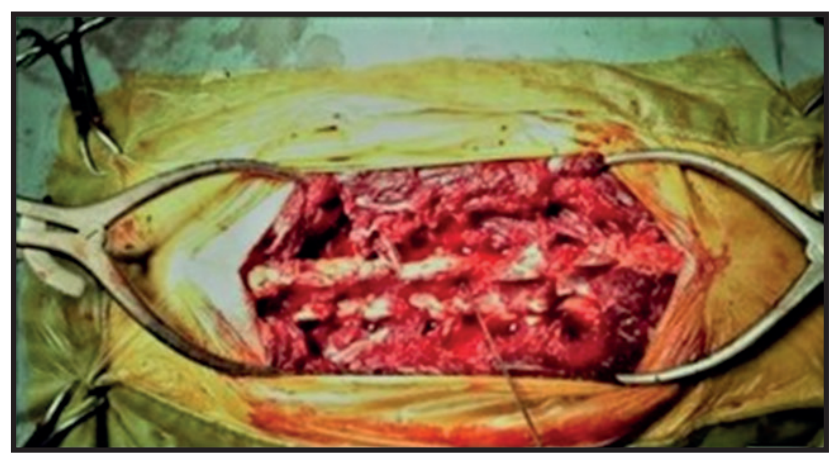

Figure 3. Kirschner wires placed through the caudal articular facets of the fourth lumbar vertebra to provide initial stability.

and morphine ${ }^{1}\left[\right.$ Dimorf $^{\circledR} 0.1 \mathrm{mg} / \mathrm{kg}$ ] was performed. The lumbosacral puncture for epidural infiltrative analgesia was made correctly although tachycardia and hypertension were observed. These alterations were compatible with nociception. For this reason, an analgesic alternative using continuous infusion of fentanyl $\mathrm{l}^{1}$ [Fentanest ${ }^{\circledR} 10 \mu \mathrm{g} / \mathrm{mg} / \mathrm{h}$ (IV)], lidocaine without vasoconstrictor ${ }^{6}\left[\right.$ Anestt ${ }^{\circledR} 50 \mu \mathrm{g} / \mathrm{kg} / \mathrm{min}$ (IV)] and ketamine $^{7}\left[\operatorname{Ketalar}^{\circledR} 20 \mu \mathrm{g} / \mathrm{kg} / \mathrm{min}\right.$ (IV)] was performed during the surgery.

The dog was positioned in ventral recumbency for surgery, and a dorsal midline incision was made from the second lumbar vertebra to the sixth lumbar vertebra. The lumbar fascia was dissected down to expose the second, third, fourth, fifth and sixth lumbar spinous processes, thus a total section of the spinal cord was observed. Using periosteal elevators, all muscular attachments were elevated from both sides of the pedicles and retracted laterally to the level of the articular processes (Figure 2). The fracture-luxation was reduced manually followed by laminectomy and then stabilisation. Two crossed $1.5 \mathrm{~mm}$ Kirschner wires were placed through the caudal articular facets of the fourth lumbar vertebra to provide initial stability (Figure 3). Two $2.0 \mathrm{~mm}$ Steinmann pins were placed at $60^{\circ}$ angle of the bodies of the second and fifth lumbar vertebrae, and third and fourth lumbar vertebrae. The pins were inserted in mediolateral direction, cranioventrally in the second and third lumbar vertebrae and caudoventrally in the fourth and fifth lumbar vertebrae. This procedure was repeated on the other side of the vertebral bodies. The pins were bent and cut sufficiently to support the polymethylmethacrylate bone cement, and transoperative radiographs taken (Figure 4).

Sixty g of polymethylmethacrylate bone cement was prepared by mixing liquid monomer with polymer powder for approximately 4 min until it reached an adequate consistency which did not stick to the gloves. The polymethylmethacrylate was applied,

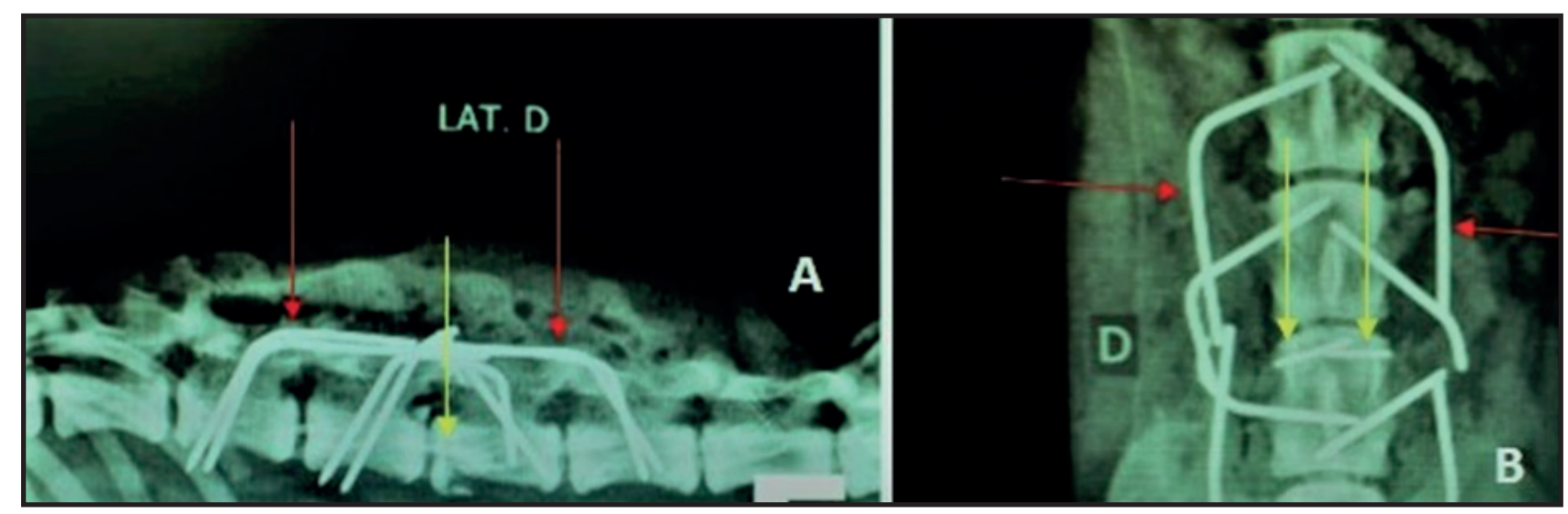

Figure 4. Transoperative radiographs showing reduction and stabilisation with two crossed $1.5 \mathrm{~mm}$ Kirschner wires placed through the caudal articular facets of the fourth lumbar vertebra (yellow arrows) and $2.0 \mathrm{~mm}$ Steinmann pins placed at $60^{\circ}$ angle of the bodies of the second and fifth lumbar vertebrae, and third and fourth lumbar vertebrae (red arrows). A- Latero-lateral projection; B- Dorsoventral projection ( $40 \mathrm{kVp}, 40 \mathrm{mAs})$. 
incorporating all Steinmann pins on either side of the dorsal spinous processes. The hardening time was 5 min and a cool saline lavage was performed to protect tissues from the heat of the exothermic reaction. The fixation was checked for stability and morphine ${ }^{7}[\mathrm{Di}-$ morf ${ }^{\circledR} 0.1 \mathrm{mg} / \mathrm{kg}$ ] was instilled on the cranial medullary portion to the medullar section.

Muscular and subcutaneous tissue were closed using Sultan suture pattern and simple continuous suture pattern, respectively, using a poliglactine absorbable suture (2-0). Skin was closed with a simple interrupted suture by using a nylon non-absorbable suture (3-0).

In the immediate postoperative period was administrated dipyrone ${ }^{8}$ [Sodium Dipyrone $500 \mathrm{mg}^{\circledR}$ - $25 \mathrm{mg} / \mathrm{kg}$, subcutaneously (SC)], meloxicam ${ }^{8}$ [Elo-xicam $\left.{ }^{\circledR} 0.1 \mathrm{mg} / \mathrm{kg}(\mathrm{SC})\right]$ and acepromazine ${ }^{8}$ [Acepran ${ }^{\circledR}$ $1 \mu \mathrm{g} / \mathrm{kg}$ ] at Yin Tang acupuncture point, to keep the patient calm after awakening from anesthesia. For management of postoperative pain was prescribed dipyrone $^{8}$ [Sodium Dipyrone ${ }^{\circledR} 500 \mathrm{mg}-20 \mathrm{mg} / \mathrm{kg}$, orally (VO)] every $6 \mathrm{~h}$ daily for 5 days, meloxicam ${ }^{8}$ [Elo-xicam ${ }^{\circledR} 0.1 \mathrm{mg} / \mathrm{kg}$ VO] every $24 \mathrm{~h}$ daily for 5 days and cephalexin $^{8}$ [Cephalexin $500 \mathrm{mg}^{\circledR}$ - $30 \mathrm{mg} / \mathrm{kg}$ (VO)] every $12 \mathrm{~h}$ daily for 15 days. The owner was advised to keep the dog at rest and restricted movement. Physical therapy was indicated in order to establish the rebalancing and pain control.

Fifteen days after surgery, the patient was attended at School Veterinary Hospital for removing the skin suture, and no changes were observed. The dog was still paraplegic without any pain and used a wheelchair to assist in locomotion (Figure 5). Although it still had urinary and faecal incontinence, and no tail control. Six months after the surgery there was not observed any changes marked, and the implants were not removed.

\section{DISCUSSION}

Lumbar vertebral injuries, as in the present case frequently, occur secondary to severe trauma (e.g. hit by car) and seem to have a characteristic fracture pattern [13]. Dorsocranial displacement of the caudal segment was associated with extrinsic forces [11]. On the other hand, cranioventral displacement of the caudal segment was considered to be a result of extrinsic forces acting on the sacrum and pelvis [12].

The dog of the present case was an intact male dog and the literature related that no-neutered males have higher prevalence of street access [2]. The patient

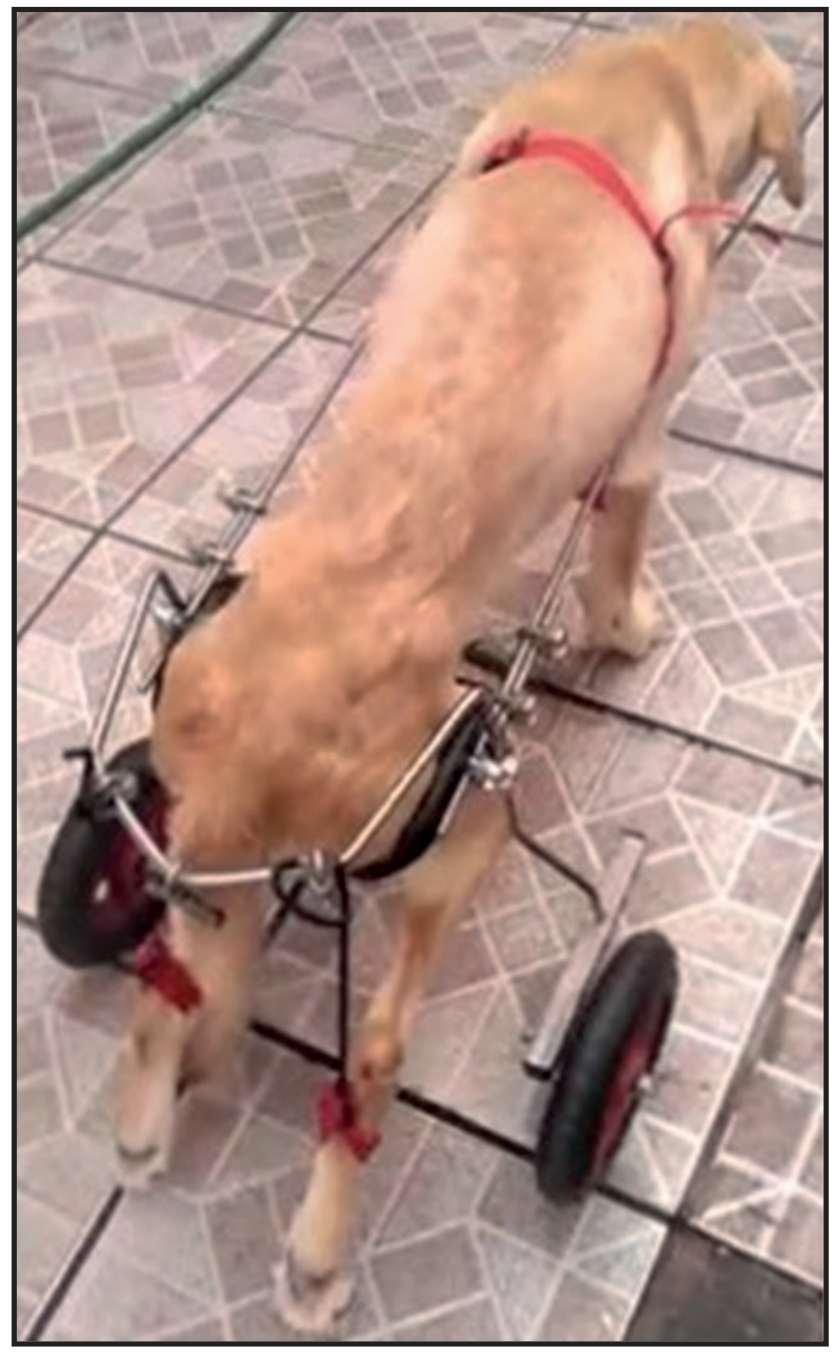

Figure 5. Dog using a wheelchair to assist in locomotion after 15 days after surgery.

became paraplegic due to spinal cord injury and failure of sensitivity and elimination of urine and feces $[9,11,15]$ which can be associated with progressive destruction of neuronal tissue due to secondary vascular and inflammatory events $[3,13,14]$.

The diagnosis of injuries to the spine and spinal cord includes anamnesis, clinical and neurological examination and imaging diagnosis [1]. The radiographic exam was used to confirm the spinal injury and determine whether by conservative or surgical treatment, corroborated with literature $[11,20]$. However, there are limitations concerning the use of radiographic exam which include moderate sensitivity regarding the presence of intrinsic bone fragments in the vertebral cavity, and identification of moderate subluxations [11]. Computed tomography (CT) and magnetic resonance imaging (MRI) were other tools that assist in the diagnosis of spinal disorders $[10,18]$. Both these 
techniques are expensive and are not available in all veterinary hospitals [11].

The treatment of the present case choice was related to the number of fractured compartments and presence or not of compression. Fractures in 2 or more compartments are indicative of surgical treatment, similar to the present case [11]. Surgical treatment by open reduction and internal fixation by using Steinmann pins and polymethylmethacrylate was performed as recommended by literature $[7,8,19]$. Other surgical techniques for repair of fracture-luxations of the fourth lumbar vertebra include vertebral body plates or spinous process and cortical screws $[6,16]$. These techniques can be used alone or associated to obtain better stabilisation [11]. Implant migration and loss of fracture reduction can be reported as complications of these techniques [12].

Steinmann pins were used to make a rigid fixing system as the block plates used for the same function [21]. The target point of lumbar vertebral implants is located between the base of the accessory process in the dorsal orientation and the transverse process in the ventral direction [21].

The advantages of using Steinmann pins and polymethylmethacrylate for fracture stabilisation in the fourth lumbar vertebrae were: better visualization and protection of spinal nerves and blood vessels [21], less damage of soft tissue during dissection than other techniques [21,22]. On the other hand, bone screws are more resistant to pull out and are less likely to migrate in comparison to Steinmann pins [22].

Polymethylmethacrylate may also become a complication due to the infection, and antibiotics incorporated into the polymer powder before mixing can be a method to prevent transoperative infection [22].
In the present case, antibiotics were used after surgery for 15 days and were effective since the dog did not show signs of infection, similar to the literature [19].

The adequate stabilisation obtained in this case report was associated with early diagnosis and treatment fracture of the implant and use of adequate amounts of polymethylmethacrylate [4]. In this case report were used $60 \mathrm{~g}$ of polymethylmethacrylate as recommended by literature [5] which suggested that $20 \mathrm{~g}$ for dogs less than $15 \mathrm{~kg}$ and 40 to $60 \mathrm{~g}$ for dogs above $15 \mathrm{~kg}$.

The prognosis was considered unfavorable since the patient had a loss of sensation of deep pain, and thus indicative of paraplegia. For this reason, rehabilitation through physiotherapy was indicated to decrease the patient's pain [17].

According to the characteristics of the present case report, the use of Steinmann pins and polymethylmethacrylate for repair of transversal fracture through the body of the fourth lumbar vertebra, with dorsocranial displacement of the caudal fragment seems to provide an effective and practical means of stabilisation, promoting decompression, and thus, improving the patient's quality of life.

\section{MANUFACTURERS}

${ }^{1}$ Cristália Produtos Químicos Farmacêuticos Ltda. Itapira, São Paulo, SP, Brazil.

${ }^{2}$ Minxray Inc. Northbrook, IL, U.S.A.

${ }^{3}$ Produtos Roche Quimicos e Farmaceuticos S/A. Rio de Janeiro, RJ, Brazil.

${ }^{4}$ AstraZeneca do Brasil Ltda. Cotia, SP, Brazil.

${ }^{5}$ Virbac do Brasil Indústria e Comércio Ltda. São Paulo, SP, Brazil.

${ }^{6}$ Syntec do Brasil Ltda. Santana de Parnaíba, SP, Brazil.

${ }^{7}$ Laboratórios Pfizer Ltda. Itapevi, SP, Brazil.

${ }^{8}$ EMS S/A. Hortolândia, SP, Brazil.

Declaration of interest. The authors report no conflicts of interest. The authors alone are responsible for the content and writing of this paper.

\section{REFERENCES}

1 Araújo B.M., Arias M.V.B. \& Tudury E.A. 2009. Paraplegia aguda com perda da percepção de dor profunda em cães: revisão de literatura. Clínica Veterinária. 14(81): 70-82.

2 Araújo B.M., Fernandes T.H.T., Baraúna Junior D., Bonelli M.A., Amorim M.M.A. \& Tudury E.A. 2017. Estudo clínico e epidemiológico em cães com fraturas e luxações vertebrais toracolombares. Pesquisa Veterinária Brasileira. 37(8): 866-870.

3 Arias M.V.B., Severo M.S. \& Tudury E.A. 2007. Trauma medular em cães e gatos: revisão da fisiopatologia e do tratamento médico. Semina: Ciências Agrárias. 28(1): 115-134.

4 Beaver D.P., Macphersont G.C., Muir P. \& Johnson K.A. 1996. Methylmethacrylate and bone screw a repair of seventh lumbar vertebral Fracture-luxations in dogs. Journal of Small Animal Practice. 37(8): 381-386.

5 Blass C.E. \& Seim H.B. 1984. Spinal fixation in dogs using Steinmann pins and methylmethacrylate. Veterinary Surgery. 13(4): 203-210. 
6 Camacho D.P., Svidzinski T.I.E., Furlaneto M.C., Lopes M.B. \& Corrêa G.O. 2014. Resinas acrílicas de uso odontológico à base de polimetilmetacrilato. Brazilian Journal of Surgery and Clinical Research. 6(3): 63-72.

7 Camargo M.H.B., Carneiro P.M., Ganzagi D., Corrêa A.F., Fiorato C.A., Mendes L.M.P., Moro S.P. \& Conti J.B. 2017. Osteossíntese vertebral lombar em cão utilizando parafusos corticais e polimetilmetacrilato odontológico - Relato de Caso. Revista de Ciência Veterinária e Saúde Pública. 4(1): 33-38.

8 Duarte M.M., Santos P.V.G.R., Costa S.D.P., Melo K.M.S., Santos T.G.R. \& Silva F.L. 2016. Trauma medular em região toracolombar em gato: Relato de caso. Publicações em Medicina Veterinária e Zootecnia. 10(10): 749-753.

9 Greve J.M.D., Casalis M.E.P. \& Barros Filho T.E.P. 2001. Diagnóstico e Tratamento da Lesão da Medula Espinal. São Paulo: Roca, 400p.

10 Hage C.F.N.S. \& Iwasaki M. 2009. Imagem por ressonância magnética: princípios básicos. Ciência Rural. 39(4): 1287-1295.

11 Jeffery N.D. 2010. Vertebral fracture and luxation in small animals. Veterinary Clinics of North American: Small Animal Practice. 40(5): 809-828.

12 Lewis D.D., Stampley A., Bellah J.R., Donner G.S. \& Ellison G.W. 1989. Repair of sixth lumbar vertebral fractureluxations, using transilial pins and plastic spinous process plates in six dogs. Journal of the American Veterinary Medical Association. 194(4): 538-542.

13 Mendes D.S. \& Arias M.V.B. 2012. Traumatismo da medula espinhal em cães e gatos: estudo prospectivo de 57 casos. Pesquisa Veterinária Brasileira. 32(12): 1304-1312.

14 Olby N. 2010. The pathogenesis and treatment of acute spinal cord injuries in dogs. Veterinary Clinics of North American: Small Animal Practice. 40(5): 791-807.

15 Pereira D.T., Schwab M.L., Ferrarin D.A., Ripplinger A., Aiello G., Herculano L.F., Wrzesinski M.R., Rauber J.S., Moro S.S. \& Mazzanti A. 2019. Fraturas e luxações vertebrais em cães. Acta Scientiae Veterinariae. 1684(47): 1-7.

16 Puricelli E., Nácul A.M., Ponzoni D., Corsetti A., Hildebrand L.C. \& Valente D.S. 2011. Intramuscular 30\% polymethylmethacrylate (PMMA) implants in a non-protein vehicle: an experimental study in rats. Revista Brasileira de Cirurgia Plástica. 26(3): 385-389.

17 Ramalho F.P., Formenton M.R., Isola J.G.M.P. \& Joaquim J.F.G. 2015. Treatment of intervertebral disc disease by physical therapy and rehabilitation in a dog - Case Report. Journal of Continuing Education in Animal Science of CRMV-SP. 13(1): 10-17.

18 Rocha L.M. 2015. Introdução à Tomografia Computadorizada e Ressonância Magnética: Tomografia Computadorizada. In: Feliciano M.A.R., Canola J.C. \& Vicente W.R.R. (Eds). Diagnóstico por Imagem em Cães e Gatos. São Paulo: Medvet, pp.34-39.

19 Silva S.O.S., Araújo B.M., Sousa D.K.T., Mota D.B., Sousa Junior F.L. \& Matos R.M.L. 2018. Técnica de fixação segmentar modificada com pinos de Steinmann em fratura Lombossacra entre L7 e S1: Relato de Caso. Publicações em Medicina Veterinária e Zootecnia. 12(6): 1-4.

20 Thomas W.B. 2000. Diskospondylitis and other vertebral infections. Veterinary Clinics of North American: Small Animal Practice. 30(1): 169-182.

21 Walker T.M., Pierce W.A. \& Welch R.D. 2002. External Fixation of the Lumbar Spine in a Canine Model. Veterinary Surgery. 31(2): 181-188.

22 Wheeler S.J. \& Sharp N.J H. 1994. Small Animal Spinal Disorders: Diagnosis and Surgery. 2nd edn. London: Mosby-Wolfe, 722p. 